Article

\title{
Co-Immobilization of Xylanase and Scaffolding Protein onto an Immobilized Metal Ion Affinity Membrane
}

\author{
Ho-Lam Wong ${ }^{1}$, Nien-Jen $\mathrm{Hu}^{2}{ }^{\mathbb{D}}$, Tzong-Yuan Juang ${ }^{3, * \mathbb{D}}$ and Yung-Chuan Liu ${ }^{1, * \mathbb{D}}$ \\ 1 Department of Chemical Engineering, National Chung Hsing University, Taichung 402, Taiwan; \\ k0kcodk0@gmail.com \\ 2 Graduate Institute of Biochemistry, National Chung Hsing University, Taichung 402, Taiwan; \\ njhu@nchu.edu.tw \\ 3 Department of Cosmeceutics, China Medical University, Taichung 404, Taiwan \\ * Correspondence: tyjuang@mail.cmu.edu.tw (T.-Y.J.); ycliu@dragon.nchu.edu.tw (Y.-C.L.)
}

Received: 3 November 2020; Accepted: 30 November 2020; Published: 2 December 2020

check for updates

\begin{abstract}
Lignocellulosic biomass conversion technology seeks to convert agricultural waste to sugars through the use of various cellulases and hemicellulases. In practice, the application of free enzymes might increase the cost of the process due to difficulties with recovery of the enzymes and products. Immobilization might be an effective approach for recovering the hydrolysis products and improving the stability and reusability of the enzymes. In this study, we used a recombinant genetic engineering approach to construct a scaffold protein gene (CipA) and a xylanase gene $(\mathrm{XynC})$ fused to a dockerin gene (DocT). After expressing CipA and XynC-DocT (XynCt) genes using E. coli hosts, the crude extracts were collected. An immobilized metal ion affinity membrane $/ \mathrm{Co}^{2+}$ ion $\left(\mathrm{IMAM}-\mathrm{Co}^{2+}\right)$ system was prepared to adsorb CipA in its crude extract, thereby allowing simultaneous purification and immobilization of CipA protein. A similar approach was applied for the adsorption of XynCt protein, exploiting the interaction between the cohesin units in IMAM-Co ${ }^{2+}$-CipA and the dockerin unit in $\mathrm{XynCt}$. The activity of the xylanase unit was enhanced in the presence of $\mathrm{Co}^{2+}$ for both the free XynCt enzymes and the immobilized CipA-XynCt. The heat resistance and stability over a wide range of values of $\mathrm{pH}$ of the immobilized CipA-XynCt were superior to those of the free XynCt. Furthermore, the immobilized CipA-XynCt retained approximately $80 \%$ of its initial activity after seven reaction cycles. The values of $K_{\mathrm{m}}$ and $\nu_{\max }$ of IMAM-Co ${ }^{2+}-\mathrm{CipA}-\mathrm{XynCt}_{\mathrm{n}}(1.513 \mathrm{mg} / \mathrm{mL}$ and $3.831 \mathrm{U} / \mathrm{mg}$, respectively) were the best among those of the other tested forms of XynCt.
\end{abstract}

Keywords: immobilized metal ion affinity membrane; xylanase; enzyme immobilization; scaffolding protein; kinetic study

\section{Introduction}

Hemicellulose is the second largest chemical component of woody and grassy biomass, and is linked with cellulose in the cell walls of almost all terrestrial plants [1,2]. The main component of hemicellulose is xylan, which accounts for one-third of the lignocellulosic materials on earth [3]. As an alternative chemical treatment, the use of enzymes for the degradation of celluloses has the advantages of environmental friendliness, good specificity, and lower by-product formation $[4,5]$. The structure of xylan is as complex as that of cellulose. The side chains of xylan must be cleaved before the xylan backbone can be completely hydrolyzed, necessitating several enzymes with different specificities to complete its hydrolysis. Nevertheless, because xylan does not form a densely packed crystal structure as cellulose does, it is more readily hydrolyzed enzymatically [6]. It has been revealed that the activity 
of xylanase could be increased by coupling to scaffolding protein [7]. Scaffolding protein is a large protein constructing the main backbone of cellulosome. It can integrate various cellulose hydrolysis enzymes through the close interaction between the cohesin and dockerin regions, and binds to the cellulose substrate with the help of the carbohydrate binding domain (CBD) to decompose cellulose in a more efficient manner.

The catalytic effects of enzymes can be inactivated upon storage, operation, and other conditions. Furthermore, when enzymes are water-soluble, they are not easy to recycle and reuse. These shortcomings greatly restrict the applicability of enzymes. Accordingly, many attempts have been made, including using inorganic carriers, to adsorb enzymes or organic polymers to immobilize enzymes through covalent bonds [8-11]. The production of cellulase and hemicellulase using recombinant $E$. coli typically produces large amounts of undesired proteins. For effective hydrolysis, enzyme purification is sometimes needed. The most common purification technique for recombinant proteins is immobilized metal affinity chromatography (IMAC). Transition metal ions (e.g., $\mathrm{Cu}^{2+}, \mathrm{Ni}^{2+}$, and $\mathrm{Co}^{2+}$ ) are first chelated to the carrier [12,13]; specific affinity between the chelated ions and the amino acid residues of the target protein allows the protein to be adsorbed [14,15]. The selection of the metal ion must be made judiciously to ensure the effective adsorption of a particular protein [16]. In IMAC processing [17,18], granular solid carriers are commonly used, although they can lead to a high pressure drop during the flow and sometimes would block the reaction. To overcome this drawback, immobilized metal ion affinity membranes (IMAMs) have been developed for enzyme purification [19-22]. These membranes have porous structures, providing a low pressure drop, which are readily loaded and prepared with inexpensive costs. Many membrane materials (e.g., cellulose acetate, cellulose nitrate, and regenerated cellulose) have been employed to prepare IMAMs. Among them, regenerated cellulose membrane (RCM) displays particularly good biocompatibility, low non-specific adsorption, strong mechanical properties, high hydrophilicity, and chemical stability. Furthermore, the abundant $\mathrm{OH}$ groups on RCMs allow their ready modification to present various functional groups for chelating a range of metal ions [23]. In our previous research, we have tested the various modification conditions on RCM morphology and pressure drops, and we find a best modification condition that the pressure drop of modified RCM would give the least impact [23]. In addition, we have also packed the immobilized IMAM in a column reactor for practicing the continuous-flow adsorption operation, which exhibits a good operation performance [20,24]. Therefore, it is highly likely that the use of immobilized enzymes in membrane column bioreactors might have potential in future industrial applications.

Several reports of the immobilization of xylanase have appeared previously. Pal et al. used a response surface methodology to optimize the process of covalently immobilizing xylanase on the surface of glutaraldehyde-alginate beads; their immobilized enzyme could be reused five times with $85 \%$ of the activity retained [25]. Santos et al. immobilized xylanase in poly(vinyl alcohol) fibers, resulting in a high hydrolysis rate of $406.7 \mu \mathrm{M} / \mathrm{min}$ at $\mathrm{pH} 6$ and $70{ }^{\circ} \mathrm{C}$ [26]. Singh et al. immobilized xylanase on synthesized silica-coated magnetite nanoparticles through ethyl carbodiimide coupling; the covalently bonded immobilized enzyme retained $90 \%$ of its activity after undergoing 10 reaction cycles [27].

Enzyme immobilization can be an efficient way of stabilizing enzymes to enable their repeated use at lower cost. Nevertheless, the immobilization process is usually complex, owing to the need for a purified enzyme, inevitably increasing the amount of advanced labor required. In previous studies, we adopted a simultaneous purification and immobilization approach, through direct IMAM contact, for the crude extracts of penicillin $G$ acylase and D-hydantoinase [28,29]. Although the results were positive, this approach was limited to the adsorption of only a single target protein in each case. To the best of our knowledge, no previous attempts have been made to co-immobilize both CipA and XynC-DocT $(\mathrm{XynCt})$ proteins with their crude extracts.

In the present study, the $\mathrm{CipA}, \mathrm{XynC}$, and DocT genes originated from the cellulosome gene of Clostridium thermocellum [30]. Due to easy cloning application, the original scaffolding protein CipA with nine cohesin domains was reduced to three cohesins, and original one CBD domain was retained. 
We produced a crude extract of the recombinant CipA and XynCt proteins. We prepared an IMAM through modification of RCM and then selected a metal ion $\left(\mathrm{Co}^{+}\right)$favorable for the co-immobilization of CipA and XynCt. Figure 1 provides a schematic representation of the preparation and immobilization processes. We optimized the reaction conditions to improve the hydrolysis efficiency and stability of the immobilized enzymes. In addition, we have evaluated the kinetic properties of the IMAM-immobilized enzymes and their respective free enzymes.

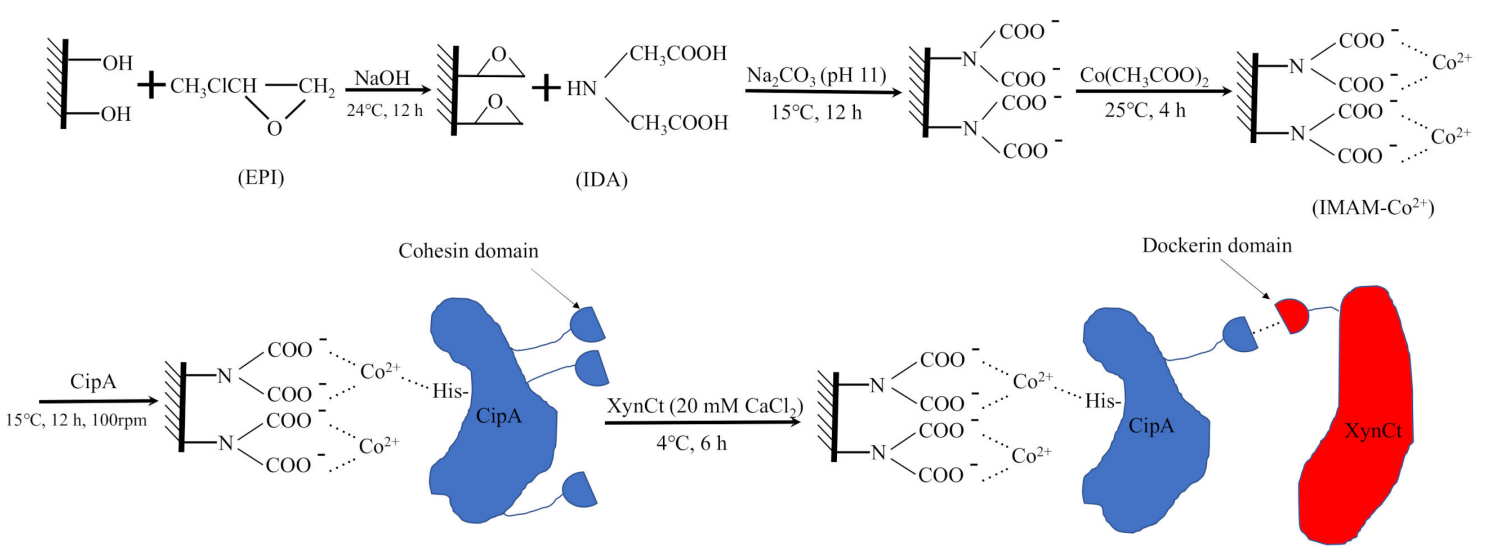

Figure 1. Schematic representation of the preparation of immobilized metal ion affinity membrane (IMAM)-Co ${ }^{2+}-\mathrm{CipA}-X y n C-D o c T(X y n C t)$. EPI, epichlorohydrin; IDA, iminodiacetic acid.

\section{Results and Discussion}

\subsection{Constructs of CipA and XynCt}

pET21d-CipA was constructed following the procedure in Figure 2a; it was transformed into E. coli DH5 $\alpha$ for preservation, and transformed into BL21(DE3), ER2566(DE3), and JM109(DE3) for expression. The procedure for xylanase gene construction is displayed in Figure $2 b$. These gene fragments of XynC and DocT were amplified using the polymerase chain reaction (PCR). DocT was first ligated to pET21b vectors, followed by ligation of XynC onto pET21b-DocT to form the construct pET21b-XynC-DocT (pET21b-XynCt), which was transformed into E. coli $\mathrm{DH} 5 \alpha$ for preservation, and transformed into E. coli, BL21(DE3), ER2566(DE3), and JM109(DE3) for expression.

\subsection{Expression of CipA and XynCt Proteins}

The obtained construct pET21d-CipA was subjected to various E. coli hosts and induction conditions to evaluate the production level of the target CipA protein. After applying the cultivation and induction conditions, a clear band of CipA protein $(98 \mathrm{kDa})$ appeared in sodium dodecyl sulfate/polyacrylamide gel electrophoresis (SDS-PAGE) (Figure S1a). The color intensity of each band, converted using ImageJ software, is presented in Figure S1b. Among the tested systems, the best induction conditions were set at $15^{\circ} \mathrm{C}$ for $24 \mathrm{~h}$ while using E. coli BL21(DE3) as the expression host.

We subjected the obtained construct $\mathrm{pET} 21 \mathrm{~b}-\mathrm{XynCt}$ to various $E$. coli hosts to test the production level of its target protein. The size of the protein XynCt is approximately $80 \mathrm{kDa}$. The results of the SDS-PAGE results are presented in Figure S2a. When using various hosts and induction conditions, a clear band appeared close to $106 \mathrm{kDa}$. The target band was measured using ImageJ software to evaluate its color intensity (Figure S2b). To further confirm the production of the proteins, we ran the SDS-PAGE and Western blots of CipA and XynCt and the results are shown in Figure S3. The host E. coli ER2566(DE3) produced the highest level of the target protein when the induction conditions were set at $37^{\circ} \mathrm{C}$ for $6 \mathrm{~h}$, while the host E. coli BL21(DE3) gave the best CipA production with induction conditions set at $15^{\circ} \mathrm{C}$ for $24 \mathrm{~h}$. 


\subsection{Metal Ion Selection}

For the IMAM adsorption of an enzyme for purification, the selection of the metal ions is always the first step for preparing the IMAM. Sometimes, various metal ions can stimulate or inhibit the enzyme activity. We tested various transition metal ions for their effects on XynCt activity. The results show that the activity of $\mathrm{XynC}$ was significantly inhibited by $\mathrm{Cu}^{2+}$ (Figure 3a). Among the other tested metal ions, $\mathrm{Co}^{2+}$ and $\mathrm{Mn}^{2+}$ both increased the activity of $\mathrm{XynCt}$, but $\mathrm{Co}^{2+}$ had the highest stimulatory effect.
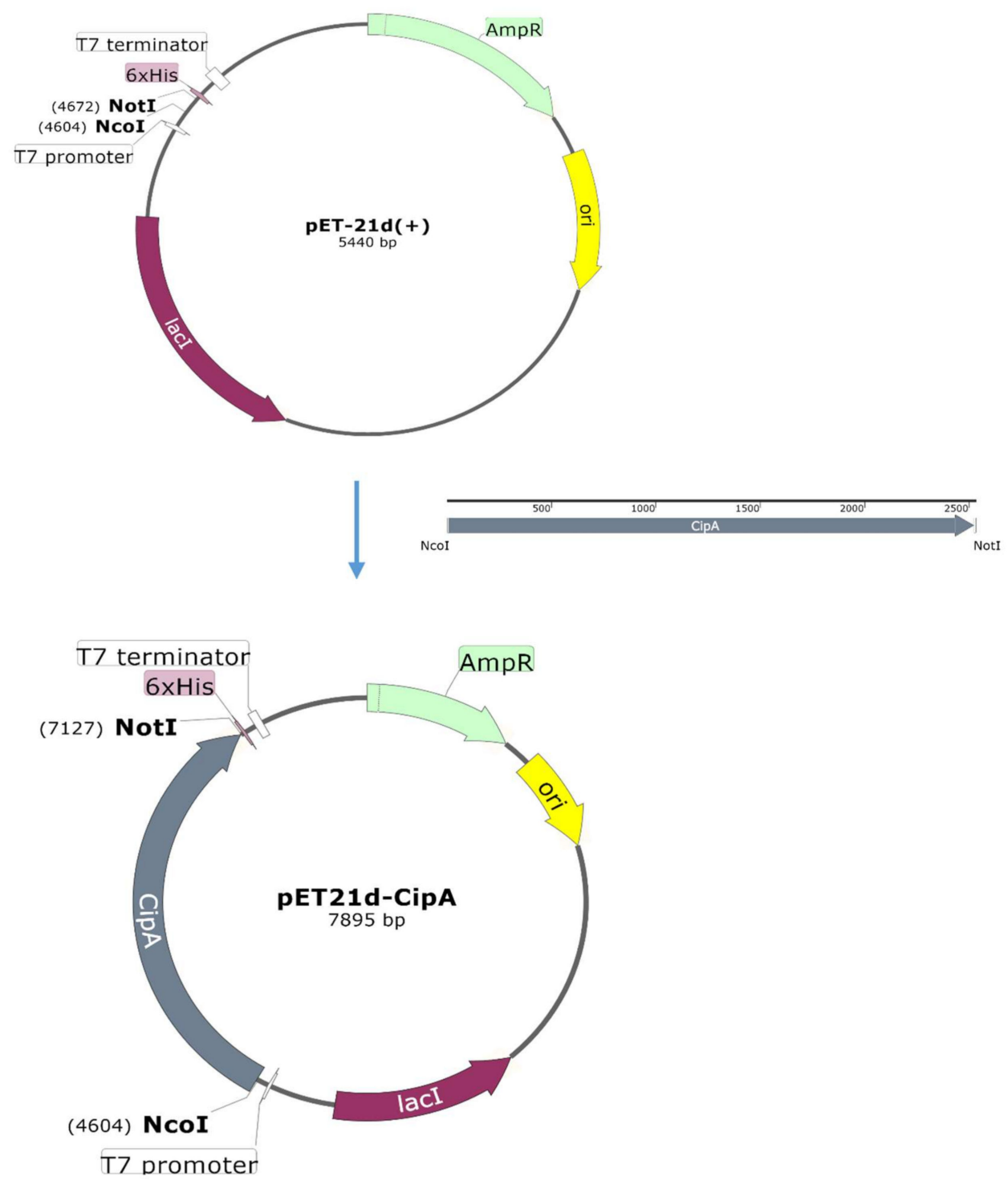

(a)

Figure 2. Cont. 

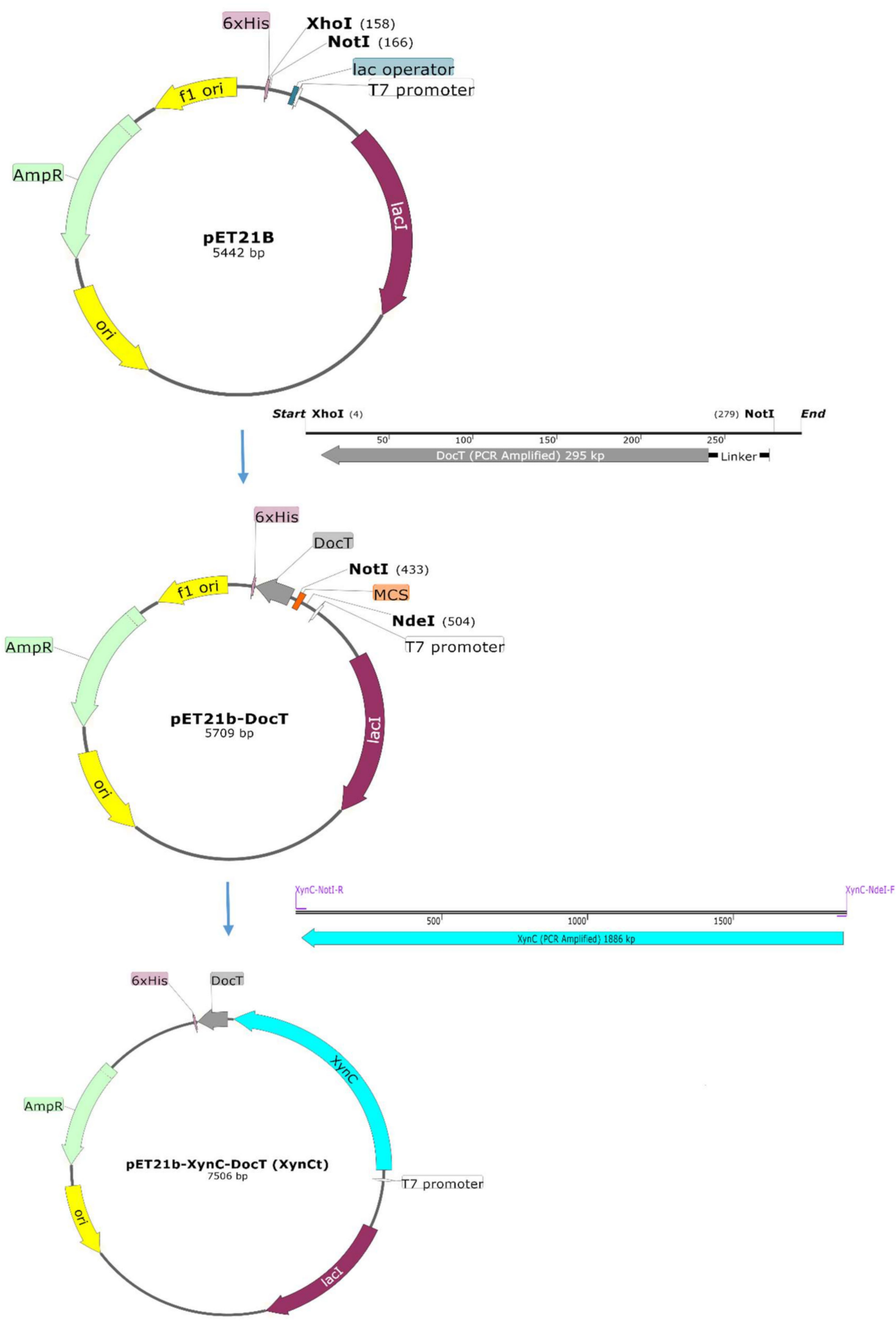

(b)

Figure 2. Plasmid construction maps of (a) pET21d-CipA and (b) pET21b-XynCt.

To determine the adsorption time for IMAM to chelate $\mathrm{Co}^{2+}$ ions, we explored the time course of the $\mathrm{Co}^{2+}$ ion adsorption. Figure $3 \mathrm{~b}$ reveals that the membrane reached its saturation adsorption level when the reaction was performed for $4 \mathrm{~h}$. Next, we tested the optimal concentration of $\mathrm{Co}^{2+}$ ions for the preparation of the IMAM. When the concentration of $\mathrm{Co}^{2+}$ ions was set at 75 or $50 \mathrm{mM}$ and the adsorption process was performed for $4 \mathrm{~h}$, the adsorption saturation level of $\mathrm{Co}^{2+}$ ion 
( $85 \mu \mathrm{mol} /$ disc) was higher than that obtained at $25 \mathrm{mM}$ (Figure $3 \mathrm{~b}$ ). Because only slight variations occurred when the concentration of $\mathrm{Co}^{2+}$ was greater than $50 \mathrm{mM}$, we used this concentration as the chelating concentration.

The role of the scaffolding protein is to link the substrate via the $C B D$, thereby allowing the enzyme to readily reach the substrate to perform the hydrolysis reaction. The amount of scaffolding protein on the membrane is a key factor for the membrane to chelate target proteins. We tested the effects of various metal ions for the IMAM to chelate the scaffolding protein CipA (Figure 3c). Although $\mathrm{Cu}^{2+}$ could adsorb the most CipA, the significant inhibition effect of $\mathrm{Cu}^{2+}$ on the activity of XynCt suggested that it would not be useful as a chelated metal ion (Figure 3a). Among the other tested metal ions, $\mathrm{Co}^{2+}$ was the only one that could adsorb CipA without inhibiting the activity of XynCt. Therefore, we selected $\mathrm{Co}^{2+}$ as our chelated metal ion for subsequent experiments.

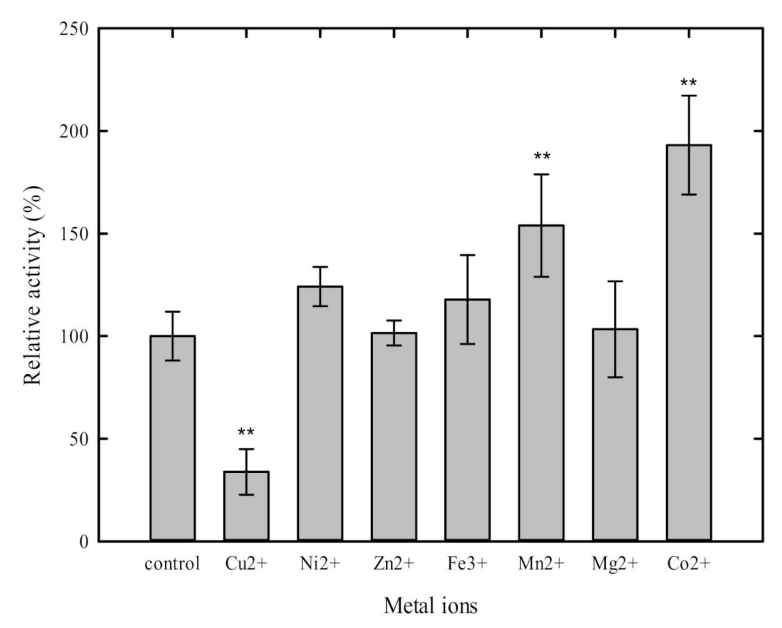

(a)

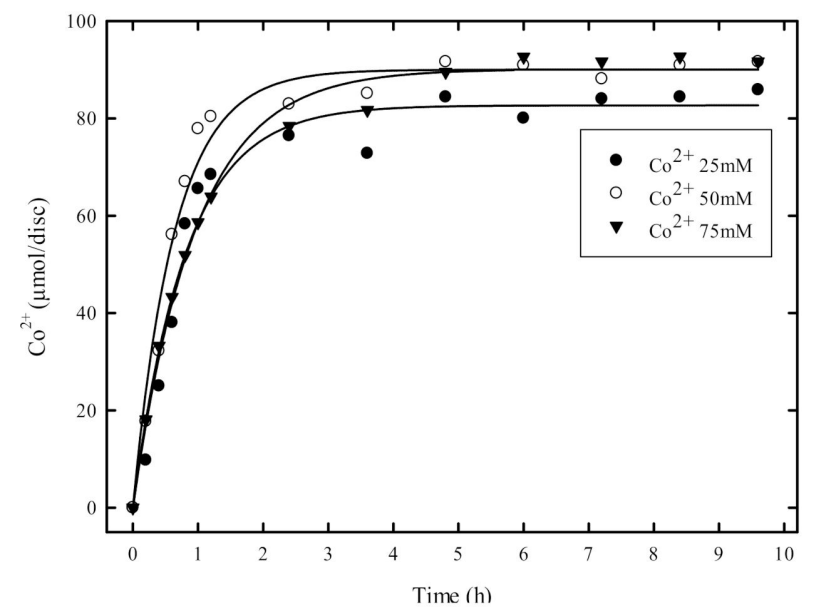

(b)

Figure 3. Cont. 


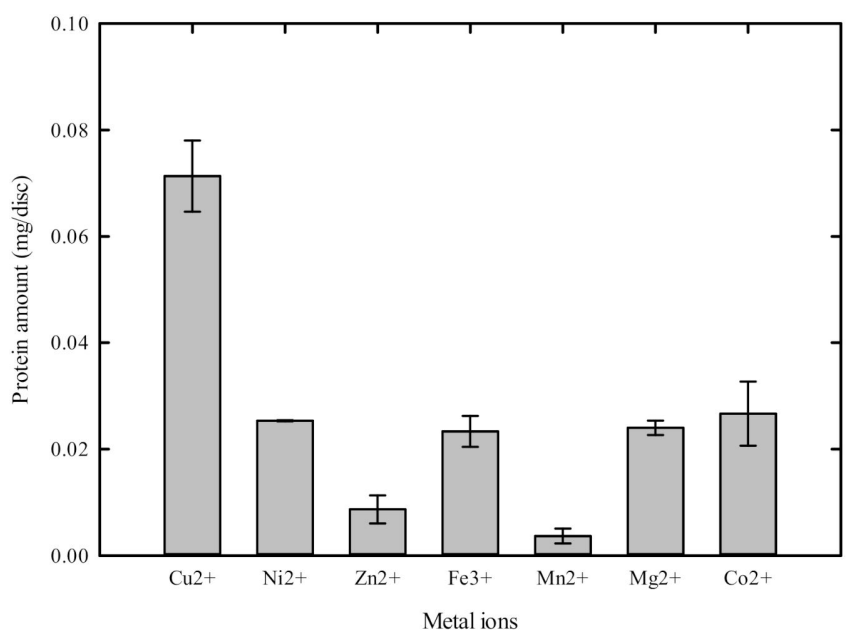

(c)

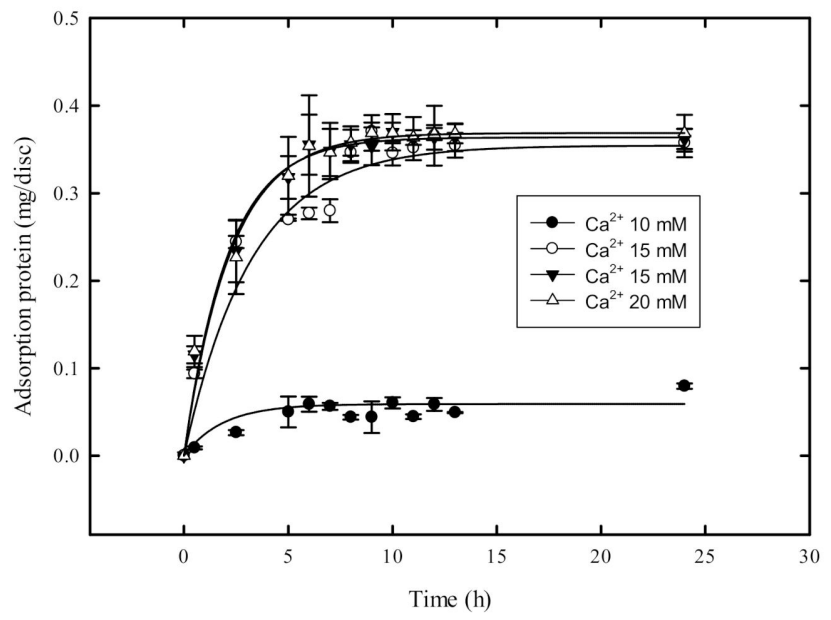

(d)

Figure 3. Characterization of the importance of cations in protein absorption and enzyme activities, (a) Effects of metal ions $(50 \mathrm{mM})$ on the activity of free $\mathrm{XynCt}$, where the asterisks $\left({ }^{* *}\right)$ indicate significant difference with $p$ values $<0.05$. (b). Effects of $\mathrm{Co}^{2+}$ concentration and adsorption time on its chelation in IMAM. (c). Effect of metal ions on CipA adsorption to the $\mathrm{Co}^{2+}$-chelated IMAM. (d) Effects of $\mathrm{Ca}^{2+}$ concentration and time on $\mathrm{XynCt}$ adsorption level on the IMAM-Co ${ }^{2+}{ }_{-} \mathrm{CipA}$. The error bars represent $\mathrm{SD}, n=3$.

It has been pointed out in the literature that $\mathrm{Ca}^{2+}$ plays a key role in maintaining the structural integrity of cellulose composites [30-32]. Since $\mathrm{Ca}^{2+}$ plays a role in constituting a compact cellulose bodies, it is assumed that the addition of $\mathrm{Ca}^{2+}$ might also favor the binding between CipA and XynCt. The protein adsorbed level under different $\mathrm{Ca}^{2+}$ concentrations and different adsorption times was tested. The results (Figure 3d) showed that the affinity binding of XynCt to CipA was significantly enhanced in the environment containing higher concentrations of $\mathrm{Ca}^{2+}(15 \mathrm{mM}, 20 \mathrm{mM}, 25 \mathrm{mM})$; while at low concentrations $(10 \mathrm{mM})$, the performance of XynCt binding was significantly weak, which proves that $\mathrm{Ca}^{2+}$ is required for $\mathrm{XynCt}$ and CipA coupling. The result also showed that the binding reaction of $\mathrm{XynCt}$ will reach saturation at about $6 \mathrm{~h}$. When the $\mathrm{Ca}^{2+}$ concentration was higher than $20 \mathrm{mM}$, the adsorption level would reveal no difference. Therefore, $20 \mathrm{mM} \mathrm{Ca}^{2+}$ was selected for the CipA and XynCt binding in the following experiments.

To explore the combined effects of various metal ions on the adsorption of CipA and xylanase, we tested six metal ions $\left(\mathrm{Co}^{2+}, \mathrm{Fe}^{3+}, \mathrm{Zn}^{2+}, \mathrm{Al}^{3+}, \mathrm{Ni}^{2+}\right.$, and $\left.\mathrm{Mn}^{2+}\right)$ on the IMAM, and then adsorbed 
CipA and xylanase in series. Thereafter, we measured the adsorption level and hydrolysis activity of the IMAM. The results are shown in Figure 4, which indicate that both $\mathrm{Co}^{2+}$ and $\mathrm{Zn}^{2+}$ could adsorb the highest level of XynCt. However, when the activity is tested, the membrane with $\mathrm{Co}^{2+}$ showed a highest activity, followed by $\mathrm{Fe}^{3+}$. Totally, $\mathrm{Co}^{2+}$ gave the highest specific activity $(0.246 \pm 0.0268 \mathrm{U} / \mathrm{mg})$, proving its effective adsorption is better than other metal ions. It is worth noting that the specific activities of $\mathrm{Mg}^{2+}$ and $\mathrm{Fe}^{3+}$ are listed as the second highest compared to other metal ions; however, the lower protein adsorption level makes them not as good that of $\mathrm{Co}^{2+}$ ions.

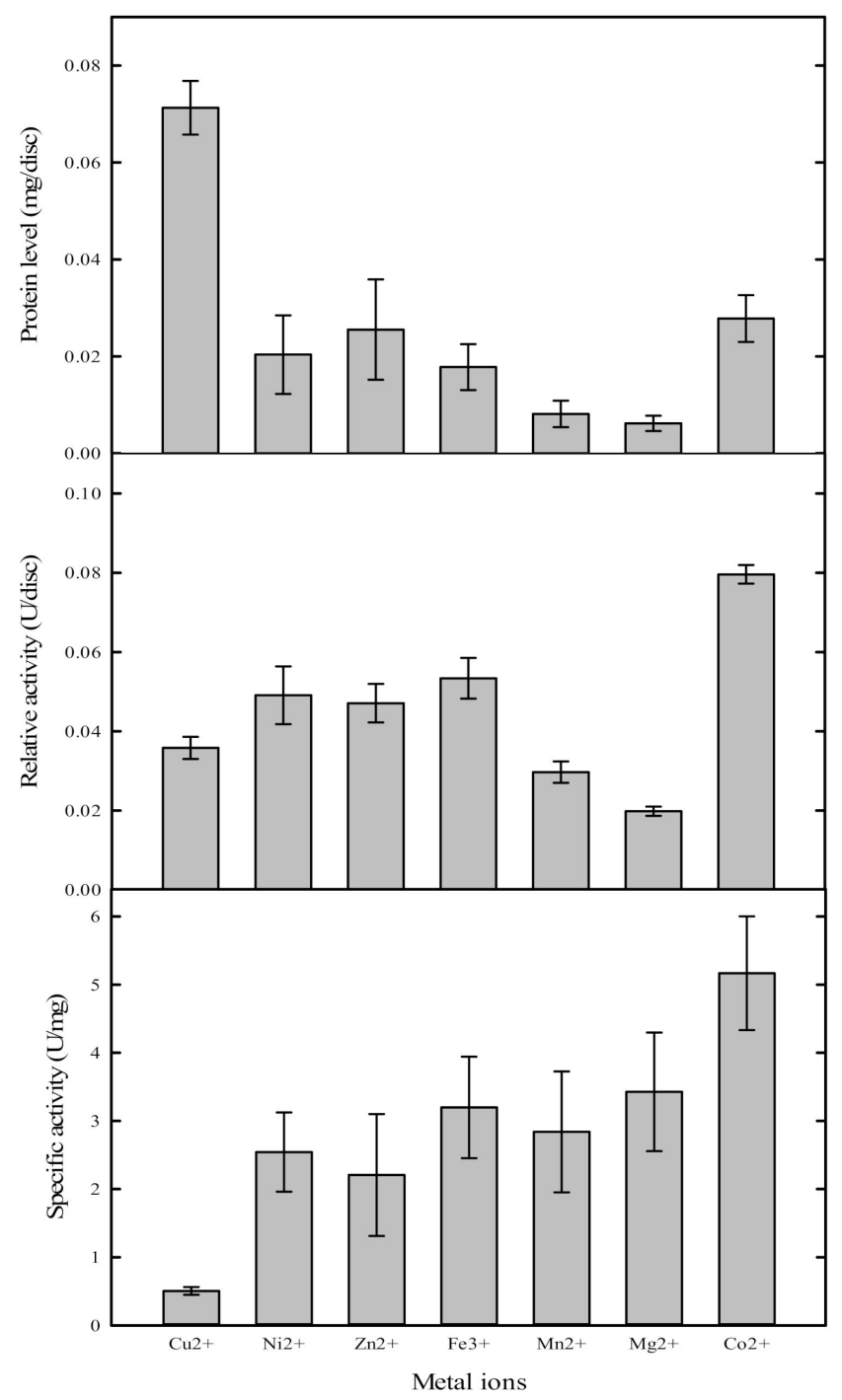

Figure 4. The effects of various metal ions on the (top) XynCt adsorption capacity, (middle) activity, and (bottom) specific activity of the IMAM-ions-CipA-XynCt. The error bars represent $\mathrm{SD}, n=3$.

\subsection{Characteristics of the Immobilized Enzyme}

The two major factors affecting the activity of an enzyme are the $\mathrm{pH}$ and the temperature. The ionic groups of an enzyme will have different degrees of protonation in environments with different values of $\mathrm{pH}$, thereby changing its configuration and, in turn, its activity. The Arrhenius equation suggests that raising the temperature increases the rate of effective collision between molecules, thereby increasing the reaction rate. Enzymes, however, are prone to protein structural changes in a higher-temperature environment, resulting in decreased activity or inactivation. Accordingly, we examined the effects of $\mathrm{pH}$ and temperature on the immobilized enzyme. 
The $\mathrm{pHs}$ we explored to measure the performance of the enzyme activity ranging from $\mathrm{pH} 4$ to 9 in Britton-Robinson buffer [33]. Figure 5a reveals that the free enzyme had its best activity when reacted at $\mathrm{pH} 6$, whereas the immobilized enzyme had its best activity at $\mathrm{pH} 7$. Because the relative activity of the immobilized enzyme was higher at a $\mathrm{pH}$ higher than that of the free enzyme, the immobilized enzyme was more resistant to alkali in the environment. Finally, we selected $\mathrm{pH} 7$ as the optimal $\mathrm{pH}$ for our subsequent experiments. It has been reported in the literature that the xylanase free enzyme derived from Myceliophthora heterothallica reveals its best activity at pH 6-7 [34]; after the xylanase derived from Bacillus pumilus was immobilized covalently to a membrane, the immobilized enzyme had excellent activity performance at $\mathrm{pH} 5-10$, whereas the free enzyme had its best activity at $\mathrm{pH} 8$ [8]. From these previous findings, it is reasonable that $\mathrm{pH} 7$ would be optimal in this present experiment.

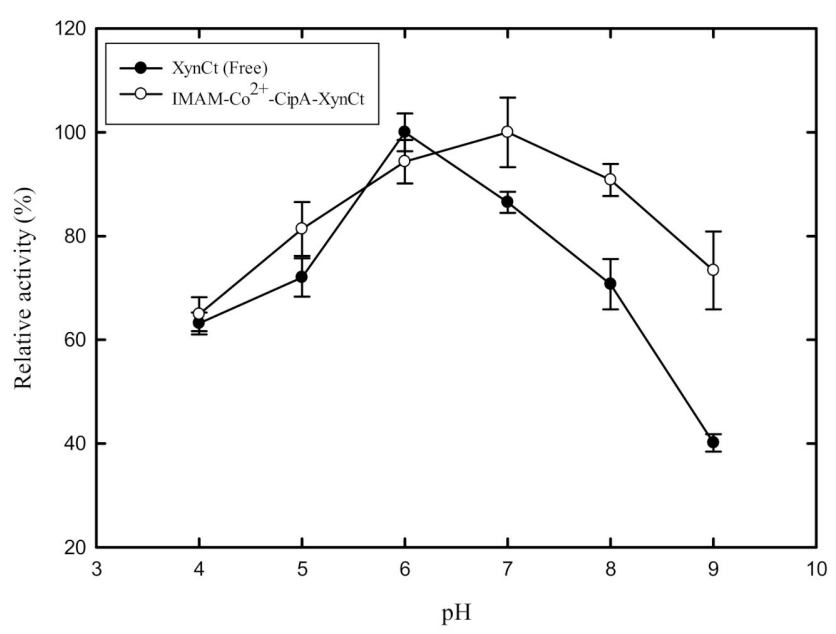

(a)

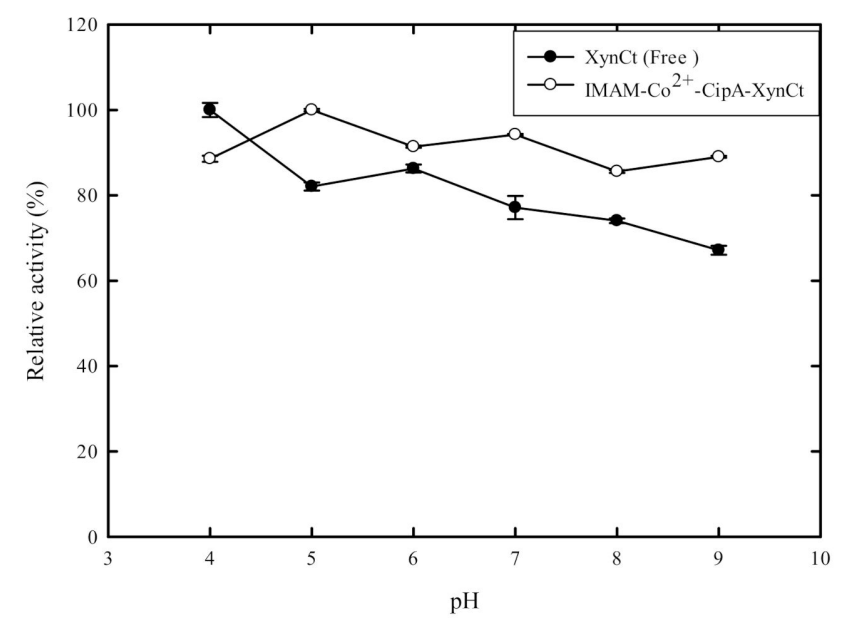

(b)

Figure 5. Cont. 


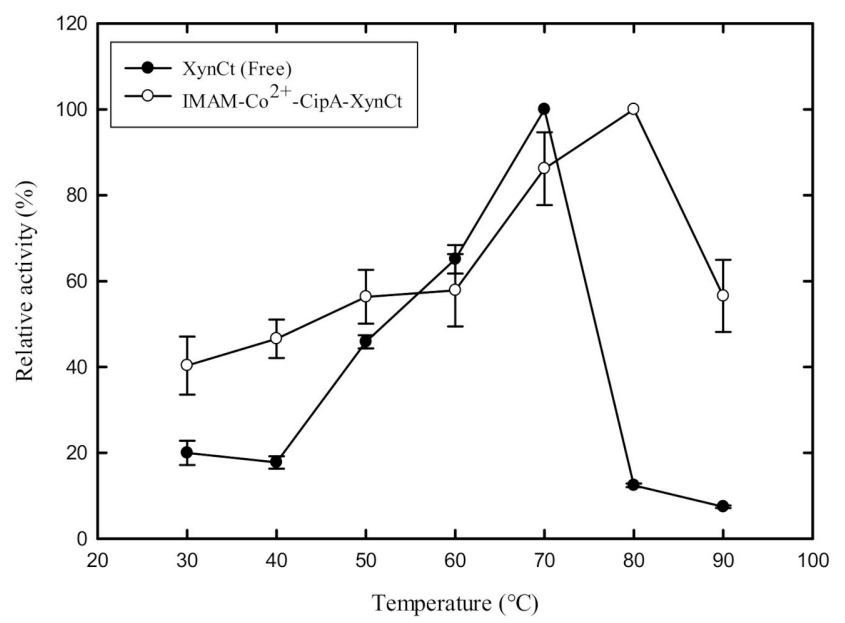

(c)

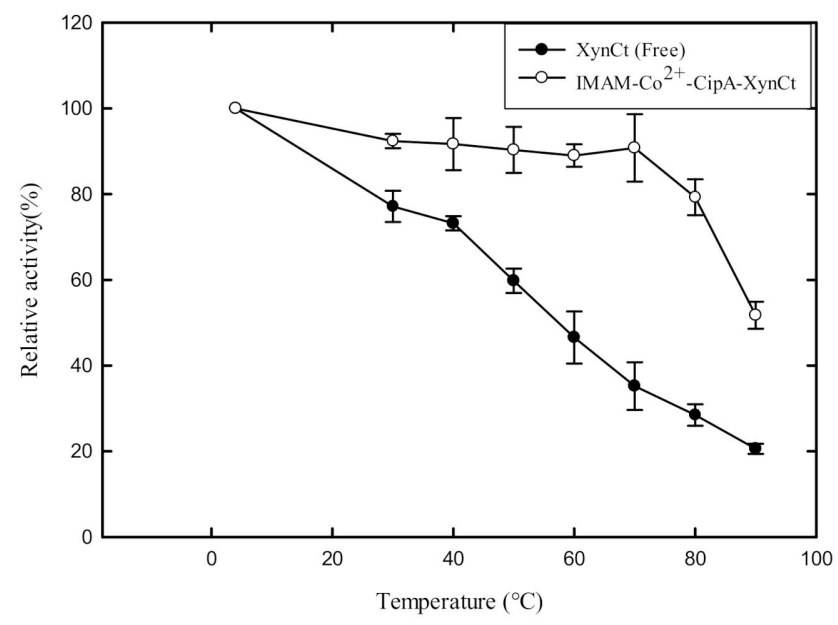

(d)

Figure 5. The effects of $\mathrm{pH}$ and temperature on IMAM-Co ${ }^{2+}-\mathrm{CipA}-\mathrm{XynCt}$ and free XynCt. (a) The enzyme activities in the range from $\mathrm{pH} 4$ to 9 in Britton-Robinson buffer and $60{ }^{\circ} \mathrm{C}$. (b) Relative enzyme activity in storage condition at the $\mathrm{pH}$ in the range from $\mathrm{pH} 4$ to $9\left(4{ }^{\circ} \mathrm{C}\right.$ in Britton-Robinson buffer for $1 \mathrm{~h}$ ). (c) The enzyme activities at the temperature range from 30 to $90{ }^{\circ} \mathrm{C}$. (d) Relative enzyme stability for storage after the treatments at different temperatures ranging from 0 to $90{ }^{\circ} \mathrm{C}$ for $1 \mathrm{~h}$. The detailed procedures were referred to in Section 3.6. The error bars represent $\mathrm{SD}, n=3$.

Because the decrease in activity of an enzyme will depend on its storage conditions, we explored whether the $\mathrm{pH}$ stability of the enzyme enhances its preservation. In the experiment, the free enzyme and the immobilized enzyme were added to Britton-Robinson buffer solutions at various values of $\mathrm{pH}$, and then placed in a refrigerator at $4{ }^{\circ} \mathrm{C}$ for $1 \mathrm{~h}$ for activity characterization. Figure $5 \mathrm{~b}$ reveals that the $\mathrm{pH}$ had little effect on the activity of the immobilized enzyme; for the free enzyme, however, the activity declined in an alkaline environment. Thus, when the enzyme was immobilized, its structural configuration was less likely to change, thereby enhancing its storage stability in environments over a greater range of values of $\mathrm{pH}$.

Next, we measured the enzyme activity at the temperature range from 30 to $90{ }^{\circ} \mathrm{C}$. Figure $5 \mathrm{c}$ reveals that the relative activity of the immobilized enzyme was better than that of the free enzyme at the various temperatures, with the optimal reaction temperature of the immobilized enzyme at $80^{\circ} \mathrm{C}$; the free enzyme revealed its best activity at $70^{\circ} \mathrm{C}$. Previous reports have indicated that the 
optimal reaction temperature of xylanase free enzyme derived from Aspergillus terreus falls between 60 and $70{ }^{\circ} \mathrm{C}$ [32], whereas, the optimal reaction temperature of most xylanases was set between 30 and $60{ }^{\circ} \mathrm{C}[27,35,36]$; furthermore, immobilization of xylanase from Thermomyces lanuginosus increased its optimal reaction temperature [27]. Therefore, it appears reasonable that $80^{\circ} \mathrm{C}$ would be the optimal reaction temperature in this present study.

When enzymes are used industrially, they will experience various temperature environments, resulting in decreased or inactivated activity. Therefore, we examined the temperature stability of the enzyme. In this experiment, we added the free enzyme and the immobilized enzyme to a buffer solution at $\mathrm{pH} 7$, and then placed the mixtures in a constant-temperature water tank at various temperatures for $1 \mathrm{~h}$ to measure their activity. Figure $5 \mathrm{~d}$ reveals that, regardless of whether it was free or immobilized, the activity of the enzyme was highest when stored at $4{ }^{\circ} \mathrm{C}$. The activity of the free enzyme stored at $40{ }^{\circ} \mathrm{C}$ for $1 \mathrm{~h}$ dropped to $73 \%$ of its initial value; in contrast, the activity of the immobilized enzyme decreased to $80 \%$ of its initial value after storing at $80^{\circ} \mathrm{C}$ for $1 \mathrm{~h}$. Thus, the immobilized enzyme was more resistant to high temperatures.

\subsection{Reusability of the Immobilized Enzyme}

Because free enzymes are difficult to separate from the products, they can be used only once. In contrast, immobilized enzymes are readily separated from their products, providing huge economic benefits in industry. Therefore, we used our enzyme immobilized under the optimized conditions as described above to explore the enzyme activity upon repeated operation. The same proportions of the reactants were used for these repeated measurements. Figure 6 reveals that after seven repeated activity tests, the activity of the immobilized enzyme was $80 \%$ of its initial activity. A previous report noted that the xylanase from Thermomyces lanuginosus, when fixed on graphene nanosheets through ion adsorption, retained approximately $60 \%$ of its initial activity after two repeated tests and approximately $40 \%$ of its initial activity after eight subsequent uses [37]. The IMAM co-immobilization of CipA and $\mathrm{XynCt}$ might be worth developing further.

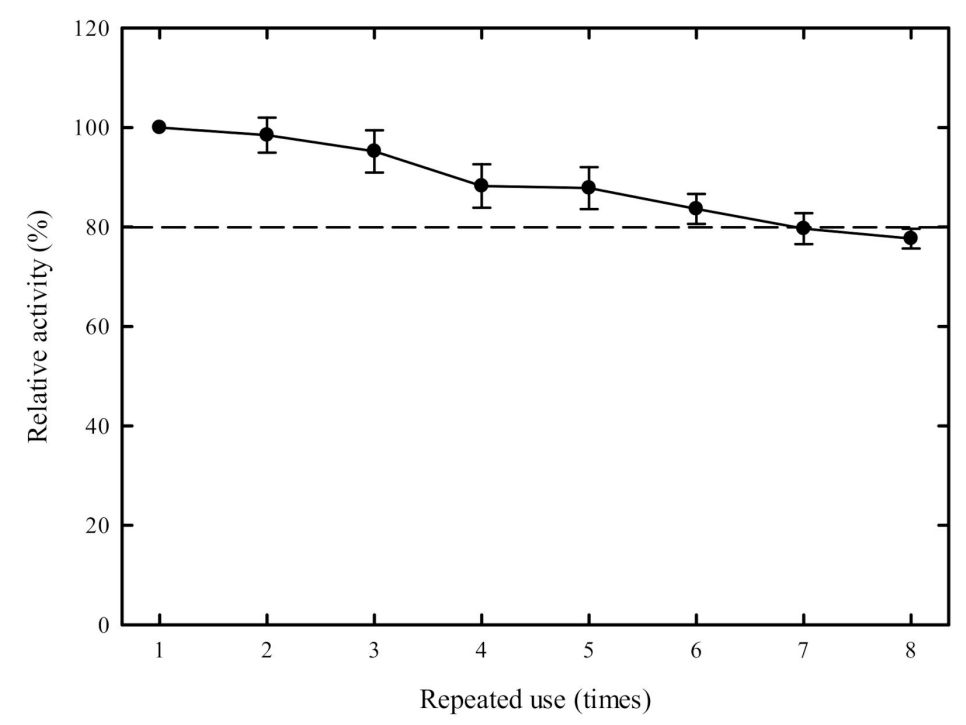

Figure 6. Reusability of IMAM-Co ${ }^{2+}-\mathrm{CipA}-\mathrm{XynCt}$. The relative enzyme activities for each repeated use were normalized with comparison to the enzyme activity of first-time use $(100 \%)$. The error bars represent $\mathrm{SD}, n=3$.

\subsection{Kinetics Analyses of Various XynC Enzymes}

To obtain the kinetic data for various XynCt enzymes, the plots of enzyme activity and substrate concentration are displayed in Figure 7. The kinetic data following Michaelis-Menten equation are obtained using the non-linear curve regression via Origin and the results are listed in Table 1. 
The order of maximum reaction rate $v_{\max }$ is IMAM-Co ${ }^{2+}-\mathrm{CipA}-\mathrm{XynCt}>\mathrm{IMAM}-\mathrm{Co}^{2+}-\mathrm{XynCt}>$ free $\mathrm{XynCt}>$ free CipA-XynCt, implicating that the immobilized enzyme can effectively enhance the hydrolysis effect, and IMAM-Co ${ }^{2+}$-CipA-XynCt has the highest $v_{\max }(3.831 \mathrm{U} / \mathrm{mg})$. It is found that IMAM coupling with only XynCt could not draw the substrate closer to XynCt due to the lack of CipA, resulting in a decreased $v_{\max }$. In contrast, the free XynCt coupling with CipA is observed to give a lower $v_{\max }$ than free XynCt. It is likely that the ineffective coupling level of CipA with $\mathrm{XynCt}$ might lead to the low reaction rate for $\mathrm{XynCt}$. On the other hand, the order of $\mathrm{K}_{\mathrm{m}}$ is IMAM-Co ${ }^{2+}-\mathrm{CipA}-\mathrm{XynCt}>\mathrm{IMAM}-\mathrm{Co}^{2+}-\mathrm{XynCt}>$ Free CipA-XynCt $>$ Free XynCt. It was found that IMAM-Co ${ }^{2+}$-CipA-XynCt has the smallest $\mathrm{K}_{\mathrm{m}}(1.513 \mathrm{mg} / \mathrm{mL})$, indicating IMAM-Co ${ }^{2+}$-CipA-XynCt has the greatest affinity for the substrate. The use of IMAM to couple both CipA and XynCt could help the enzyme hydrolysis affinity with substrate. It is likely that the substrate would not only bind to XynCt but also via the help of CBD of CipA to increase the contact probability between the substrate and the enzyme. On the other hand, the lower $\mathrm{K}_{\mathrm{m}}$ value of $\mathrm{XynCt}_{\mathrm{C}} \mathrm{CipA}$ suggested that the free XynCt-CipA has a better substrate affinity than that of free XynCt. The coupling of CipA did contribute to the affinity of XynCt with the substrate.

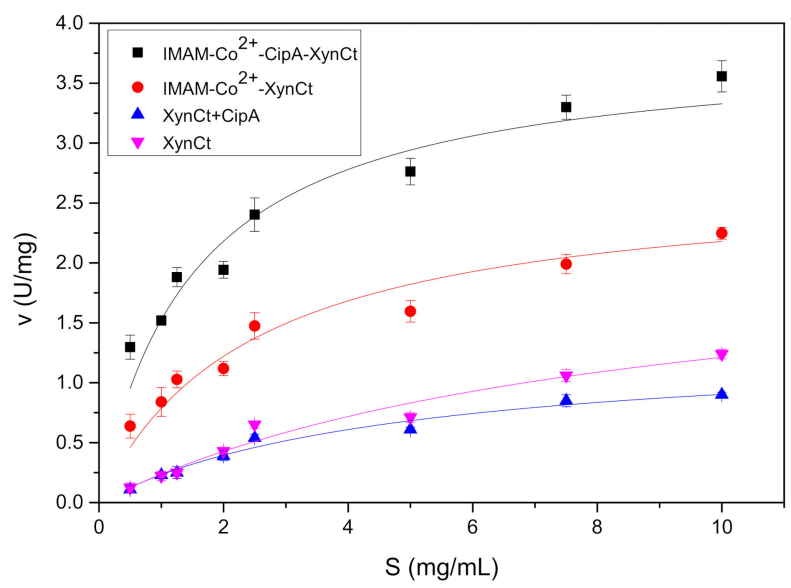

Figure 7. Michaelis-Menten plots of various immobilized and free enzymes. Symbols represent experimental data and lines represent regression results. The error bars represent $\mathrm{SD}, n=3$.

Table 1. Kinetic parameters of various types of enzymes.

\begin{tabular}{cccc}
\hline Enzyme & $\boldsymbol{R}^{\mathbf{2}}$ & $\boldsymbol{K}_{\mathbf{m}}(\mathbf{m g} / \mathbf{m L})$ & $\boldsymbol{v}_{\max }(\mathrm{U} / \mathbf{m g})$ \\
\hline XynCt & 0.963 & 8.445 & 2.235 \\
XynCt + CipA & 0.972 & 4.736 & 1.330 \\
IMAM-Co ${ }^{2+}-$ XynCt & 0.953 & 2.446 & 2.713 \\
IMAM-Co ${ }^{2+}-$ CipA-XynCt & 0.929 & 1.513 & 3.831 \\
\hline
\end{tabular}

\section{Materials and Methods}

\subsection{Chemicals, Strains, and Plasmids}

RCM (diameter: $47 \mathrm{~mm}$; average pore size: $0.45 \mathrm{~mm}$; thickness: $160 \mathrm{~mm}$ ) was purchased from Sartorius, Göttingen, Germany. Epichlorohydrin (EPI) was obtained from Tedia (Fairfield, OH, USA) and iminodiacetic acid (IDA) from Thermo Fisher Scientific (Geel, Belgium). The QIAprep ${ }^{\circledR}$ Spin Miniprep Kit used to isolate plasmid DNA was purchased from QIAGEN, Hilden, Germany. The Taq DNA polymerase was purchased from Protech Technology Enterprise Co., Taipei, Taiwan. The genes of xylanase $(\mathrm{XynC})$, scaffolding protein with $1 \mathrm{CBD}$ and 3 cohesin regions (CipA), and anchoring region protein (Dockerin, DocT) were provided by Professor WenHsiung Li of the Biodiversity Research Center of Academia Sinica, Taiwan. The E. coli host strains and vectors used in this study are listed in Table 2. Other reagents were of analytical grade and obtained from local suppliers. 
Table 2. E. coli strains and plasmids used in this study.

\begin{tabular}{|c|c|c|}
\hline Strain or Plasmid & Genotype and Relevant Characteristics & Source \\
\hline $\mathrm{DH} 5 \alpha$ & $\begin{array}{c}\mathrm{F}^{-} \text {endA1 glnV44 thi-1 recA1 relA1 gyrA96 deoR nupG } \\
\text { p } \Phi \text { 80dlacZ } \Delta \mathrm{M} 15 \Delta(\mathrm{lacZYA}-\mathrm{argF}) \mathrm{U169} \\
\text { hsdR17 }\left(\mathrm{rk}^{-} \mathrm{mk}^{+}\right), \lambda^{-}\end{array}$ & Novagen, USA \\
\hline BL21(DE3) & $\begin{array}{l}\text { E. coli str. B F } \mathrm{F}^{-} \text {ompT gal dcm lon hsdSB }\left(\mathrm{rB}^{-} \mathrm{mB}^{-}\right) \lambda \\
\text { (DE3 [lacI lacUV5-T7gene ind1 sam7 nin5]) }\left[\mathrm{malB}^{+}\right] \\
\text {K-12( } \lambda \mathrm{S})\end{array}$ & Novagen, USA \\
\hline ER2566(DE3) & $\begin{array}{c}\text { F- } \lambda \text {-fhuA2 [lon] ompT lacZ::T7 gene 1gal sulA11 } \\
\Delta \text { (mcrC-mrr)114::IS10R(mcr-73::miniTn10-TetS)2 } \\
\text { R(zob210::Tn10) (TetS) end A1 [dcm] }\end{array}$ & New England Biolabs, USA \\
\hline JM109(DE3) & $\begin{array}{l}\text { endA1 glnV44 thi-1 relA1 lon::IS186 } \\
\text { mcrB+_(lac-proAB) e14-[F' traD36 proAB+ lacIq } \\
\text { lacZ } \triangle \mathrm{M} 15] \text { hsdR17(rK } \mathrm{F}^{-} \mathrm{mK}+\lambda^{-}(\mathrm{DE} 3 \text { [lacI lacUV5-T7 } \\
\text { gene } 1 \text { ind1 sam7 nin5]) }\end{array}$ & Promega, Fitchburg, WI, USA \\
\hline pET21b and pET21d & $\begin{array}{l}\text { bacterial vectors for inducible expression of } \\
\text { N-terminally T7-tagged protein }\end{array}$ & Novagen, USA \\
\hline T-vector & pBluescript IISK(-) with modified MCS & Yeastern Biotech Co. \\
\hline CipA, DocT, XynC & $\begin{array}{l}\text { Cellulosome scaffolding gene, Dockerin gene, } \\
\text { Xylanase gene }\end{array}$ & $\begin{array}{c}\text { Professor Li } \\
\text { (Academia Sinica, Taiwan) }\end{array}$ \\
\hline
\end{tabular}

\subsection{Constructs of the XynCt and CipA}

The primers XynC-NdeI-F (5'-GGAAT TCCATATGCTGAAGAAAAAACTGTTGAC-3') and XynC-NotI-R (5'-TTTTCCTTTTCGGCCGC AAGTTCTCTCAGAACGAG-3') were designed to amplify the XynC gene. In addition, the primers DocT-NotI-F (5'-AAGGAAAAAAGCGGCCGCAGG CGGCGGCGACGAC-3') and DocT-XhoI-R (5'-AAGGAAAAAAGCGGCCGCAGGCGGCGGCGA CGAC- $3^{\prime}$ ) were designed to amplify DocT. The gene of CipA was amplified using the primers CipA1B3C-NcoI-F (5'-CATGCCATGGCAACCATGACAGTG-3') and CipA1B3C-NotI-R (5'-TTT TCCTTTTGCGGCCGCTTGTGCATCATAATCAGAAC-3'). The PCR amplification conditions are listed in Table S1. The purified XynC and DocT genes were cloned into the pET21b vector to obtain the construct pET21b-XynCt and transformed into E. coli expression strains, BL21(DE3), ER2566(DE3) and JM109(DE3). Similarly, the purified CipA gene was ligated into pET21d to obtain the construct pET21d-CipA and transformed to the three E. coli expression strains. The cloning procedures are shown in Figure 2.

\subsection{Strain Cultivation and Protein Expression}

A seed medium of Luria-Bertani (LB) broth plus ampicillin $(50 \mu \mathrm{g} / \mathrm{mL}, 10 \mathrm{~mL})$ was inoculated with the single colony and cultivated overnight at $37^{\circ} \mathrm{C}$ at $200 \mathrm{rpm}$. The seed culture was used to inoculate $(10 \%) \mathrm{LB}$ medium as the main culture; the cultivation was performed at $37^{\circ} \mathrm{C}$ and $200 \mathrm{rpm}$ to reach a cell density at optical density $600 \mathrm{~nm}$ (OD600) of 0.6-0.8. Isopropyl $\beta$-d-1-thiogalactopyranoside (IPTG) was added to reach a final concentration of $0.1 \mathrm{mM}$. The cultures were further incubated at 37 or $15^{\circ} \mathrm{C}$ and $200 \mathrm{rpm}$ for 6 or $24 \mathrm{~h}$, respectively. The harvested broth was then subjected to centrifugation (7000 rpm, $\left.4^{\circ} \mathrm{C}, 20 \mathrm{~min}\right)$ to obtain a cell pellet. The pellet was resuspended in Tris- $\mathrm{HCl}$ buffer $(20 \mathrm{mM}$ Tris- $\mathrm{HCl}, \mathrm{pH} 8.0)$ and lysed through sonication, followed by a centrifugation $\left(8500 \mathrm{rpm}, 4^{\circ} \mathrm{C}, 20 \mathrm{~min}\right)$ to obtain the supernatant (crude extract), which was collected and applied in all of the studies.

\subsection{IMAM Preparation and Enzyme Immobilization}

The IMAM was prepared according to the method described by Liu et al. [20]. Briefly, a piece of RCM was immersed in $1 \mathrm{M} \mathrm{NaOH}(20 \mathrm{~mL})$ and EPI $(5 \mathrm{~mL})$ and shaken $\left(150 \mathrm{rpm}, 24^{\circ} \mathrm{C}, 12 \mathrm{~h}\right)$. The membrane was rinsed with deionized (DI) water and then immersed in $0.2 \mathrm{M}$ IDA solution (adjusted to $\mathrm{pH} 11.0$ with $1 \mathrm{M}$ carbonate buffer; $25 \mathrm{~mL}$ ) and shaken $\left(150 \mathrm{rpm}, 15^{\circ} \mathrm{C}, 12 \mathrm{~h}\right)$. All the reactions were performed in a $250 \mathrm{~mL}$ beaker. The modified membrane was then immersed in various metal ion solutions ( $50 \mathrm{mM}, 20 \mathrm{~mL}$ ) for $4 \mathrm{~h}$. The membrane was washed with DI water to remove any unbound metal ions and give the IMAM-metal ion sample. 
The prepared IMAM-metal ion sample was immersed in $20 \mathrm{~mL}$ of crude CipA extract (protein level: $0.64 \mathrm{mg} / \mathrm{mL}$ ) in $20 \mathrm{mM}$ Tris- $\mathrm{HCl}$ buffer ( $\mathrm{pH}$ 8.0). The adsorption process was performed $15{ }^{\circ} \mathrm{C}$ and $100 \mathrm{rpm}$ for $12 \mathrm{~h}$. The unbound protein was washed out with sodium phosphate buffer ( $\mathrm{pH} 8.0)$. The IMAM-metal ion sample with adsorbed CipA was then immersed in crude XynCt extract $(20 \mathrm{~mL}$, $0.6 \mathrm{U} / \mathrm{mL}$ ) in $20 \mathrm{mM}$ Tris- $\mathrm{HCl}$ buffer ( $\mathrm{pH} 8.0$ ) containing $20 \mathrm{mM} \mathrm{Ca}^{2+}$ ions. The interaction of the cohesin and dockerin regions of the CipA and XynCt proteins was performed at $4{ }^{\circ} \mathrm{C}$ for $6 \mathrm{~h}$ to form IMAM-metal ion-CipA-XynCt.

\subsection{Assays}

The activity of xylanase was measured using xylan $(5 \mathrm{mg} / \mathrm{mL}$; Sigma, St. Louis, MI, USA) as the substrate. One piece of IMAM-CipA-XynCt or $0.5 \mathrm{~mL}$ free XynCt reacted with 1 or $0.5 \mathrm{~mL}$ substrate solution at $60{ }^{\circ} \mathrm{C} / 75 \mathrm{rpm}$ for $20 \mathrm{~min}$, respectively. The hydrolysis sample $(1 \mathrm{~mL})$ was mixed with 3,5-dinitrosalicaylic acid (DNS) solution $(1 \mathrm{~mL}$ ) and reacted for $5 \mathrm{~min}$ in boiling water to measure the reducing sugar concentration, which is related to the xylose standard curve [38]. One unit of activity is defined as the amount of enzyme required to produce $1 \mu \mathrm{mol}$ of xylose per minute. The Bradford protein assay was used to measure the total protein content [39]. Protein analysis was performed using 12\% SDS-PAGE and Coomassie Blue staining [40]. For Western blot analysis, the protein samples ran on the SDS-PAGE were transferred to polyvinylidene fluoride membrane (pore size $0.22 \mu \mathrm{m}$ ). After being blocked and washed, the membrane was incubated overnight at $4{ }^{\circ} \mathrm{C}$ with anti-6His antibody (alkaline phosphatase) $(1: 10,000)$, followed by staining using the 5-bromo-4-chloro-3-indolyl-phosphate/Nitro-Blue-Tetrazolium chromogenic system (Abcam, Cambridge, UK). ImageJ software (v. 1.49 s) was used to determine the color intensity of each band, which was used to estimate the production level of target proteins [41]. The $\mathrm{Co}^{2+}$ ions adsorbed on the IMAM were desorbed in $0.1 \mathrm{M}$ ethylenediaminetetraacetic acid (EDTA), $10 \mathrm{~mL}$ for $1 \mathrm{~h}$; the $\mathrm{Co}^{2+}$ ion-EDTA sample was then subjected to absorbance detection at $467 \mathrm{~nm}$ in an ultraviolet/visible spectrometer and was calibrated via the standard curve.

\subsection{The $\mathrm{pH}$ and Temperature Effect}

The optimal reaction $\mathrm{pH}$ was studied by incubating one disc of IMAM-CipA-XynCt or free XynCt with substrate solution at varying $\mathrm{pH}(4-9)$ Britton-Robinson buffer at $60{ }^{\circ} \mathrm{C} / 75 \mathrm{rpm}$ and then the xylanase activity was determined. The relative activity was calculated as the ratio of the activity of enzyme to that of the maximum activity. The optimal reaction temperature was tested by incubating IMAM-CipA-XynCt or free $\mathrm{XynCt}$ with substrate solution at varying temperatures $\left(30-90{ }^{\circ} \mathrm{C}\right)$ at $\mathrm{pH} 7 / 75 \mathrm{rpm}$ for $20 \mathrm{~min}$. The relative activity was calculated as the ratio of the activity of enzyme to that of the maximum activity.

The $\mathrm{pH}$ stability was studied by incubating one disc of IMAM-CipA-XynCt or free XynCt at varying $\mathrm{pH}(4-9)$ for $1 \mathrm{~h}\left(4^{\circ} \mathrm{C}\right)$ and then the xylanase activity was determined. The relative activity was calculated as the ratio of the residual activity of enzymes after incubation to that of the original activity. The thermal stability was tested by incubating IMAM-CipA-XynCt or free XynCt at temperatures $\left(0-90^{\circ} \mathrm{C}\right)$ for $1 \mathrm{~h}$ at $\mathrm{pH}$. The relative activity was calculated as the ratio of the residual activity of enzyme after incubation to that of the original activity.

To test the reusability, one disc of IMAM-CipA-XynCt was used in the repeated-use (8 times) test. The residual xylanase activity was determined. The relative activity was calculated as the ratio of the residual xylanase activity to that of the original xylanase activity.

\subsection{Kinetics Model}

The kinetics model was derived from the Michaelis-Menten equation, as follows:

$$
v=\frac{v_{\max } S}{K_{m}+S}
$$


where $S$ is the initial substrate concentration, $v$ is the reaction rate, $K_{\mathrm{m}}$ is the Michaelis-Menten constant, and $v_{\max }$ is the maximum reaction rate. A non-linear curve fitting was applied to obtain $K_{\mathrm{m}}$ and $v_{\max }$ values via the use of software Origin ver. 9.0.

Hydrolysis reactions were performed to estimate the reaction rate constants. In the tests, the initial activities of xylanase and immobilized xylanase were set at 0.64 and $0.70 \mathrm{U} / \mathrm{mg}$, respectively, while the concentration of xylan was varied from 0.5 to $10 \mathrm{mg} / \mathrm{mL}$. The activity measured at $70{ }^{\circ} \mathrm{C}$ and $\mathrm{pH} 6$ was used to represent the sample reaction rate.

\subsection{Statistical Analysis}

All the experiments were performed in triplicate; data are expressed as means $\pm S D$; significant differences between means were identified through analysis of variance (Origin v9.0, OriginLab Corporation, Northampton, MA, USA).

\section{Conclusions}

In this study, the RCM was modified to an IMAM for co-immobilization of scaffolding protein and xylanase to the hydrolysis reaction. The metal ion selection illustrated that the use of cobalt ions was the best to form the immobilized ion affinity membrane (IMAM). This study also demonstrated that the cohesin region of the scaffolding protein was capable of coupling to the dockerin region on the XynCt. The IMAM-Co ${ }^{2+}$ immobilized XynCt and CipA exhibit characteristics with higher optimal pHs and temperatures plus higher stable $\mathrm{pHs}$ and temperature ranges. In addition, it could be subjected seven times to repeated use with a retained activity of $80 \%$. The immobilized membrane possesses better kinetic parameters of both maximum reaction rate and kinetic constant compared to the free enzymes and the immobilized membrane without CipA protein. This study illustrates the feasibility of co-immobilization of CipA and $\mathrm{XynCt}$ the first time and demonstrates the benefits of the coupling of CipA to the xylanase hydrolysis reaction.

Supplementary Materials: The following are available online at http://www.mdpi.com/2073-4344/10/12/1408/s1, Figure S1: Expression levels of CipA protein using pET21d-CipA plasmid transformed in different E. coli expression strains as analyzed by SDS-PAGE and their relative color intensities, Figure S2: Expression levels of XynCt using pET21b-XynCt plasmid transformed in different E. coli expression strains as analyzed by SDS-PAGE and their relative color intensities. Figure S3: (a) SDS-PAGE and (b) Western blots for the target proteins. The cell lysates were separated to pellet and supernatant under centrifugation $\left(8500 \mathrm{~g}, 4^{\circ} \mathrm{C}, 20 \mathrm{~min}\right)$. Table S1: PCR amplification conditions for DocT, XynC, and CipA genes.

Author Contributions: Conceptualization, T.-Y.J. and Y.-C.L.; Data curation, H.-L.W. and N.-J.H.; Funding acquisition, T.-Y.J.; Methodology, H.-L.W. and N.-J.H.; Project administration, Y.-C.L.; Visualization, Y.-C.L.; Writing-original draft, Y.-C.L.; Writing—review and editing, T.-Y.J. All authors have read and agreed to the published version of the manuscript.

Funding: This study was supported by the Ministry of Science and Technology of Taiwan (grant nos. MOST 109-2221-E-005-028-MY2 and MOST 108-2221-E-005-041-MY2) and China Medical University (grant nos. CMU108-AWARD-01 and CMU-108-MF-122).

Conflicts of Interest: The authors declare no conflict of interest.

\section{References}

1. Li, L.; Rowbotham, J.S.; Greenwell, C.H.; Dyer, P.W. An introduction to pyrolysis and catalytic pyrolysis: Versatile techniques for biomass conversion. In New and Future Developments in Catalysis: Catalytic Biomass Conversion; Elsevier: Amsterdam, The Netherlands, 2013; pp. 173-208.

2. Wyman, C.E.; Decker, S.R.; Himmel, M.E.; Brady, J.W. Hydrolysis of Cellulose and Hemicellulose, in Polysaccharides: Structural Diversity and Functional Versatility, 2nd ed.; Dumitriu, S., Ed.; Marcel Dekker INC.: New York, NY, USA, 2005; pp. 995-1033.

3. Dhiman, S.S.; Sharma, J.; Battan, B. Industrial applications and future prospects of microbial xylanases: A review. Bioresources 2008, 3, 1377-1402. 
4. Gírio, F.M.; Fonseca, C.; Carvalheiro, F.; Duarte, L.C.; Marques, S.; Bogel-Łukasik, R. Hemicelluloses for fuel ethanol: A review. Bioresour. Technol. 2010, 101, 4775-4800. [CrossRef]

5. Peng, F.; Peng, P.; Xu, F.; Sun, R.-C. Fractional purification and bioconversion of hemicelluloses. Biotechnol. Adv. 2012, 30, 879-903. [CrossRef]

6. Saha, B.C. a-L-Arabinofuranosidases: Biochemistry, molecular biology and application in biotechnology. Biotechnol. Adv. 2000, 18, 403-423. [CrossRef]

7. Orita, T.; Sakka, M.; Kimura, T.; Sakka, K. Recombinant cellulolytic or xylanolytic complex comprising the full-length scaffolding protein RjCipA and cellulase RjCel5B or xylanase RjXyn10C of Ruminiclostridium josui. Enzym. Microb. Technol. 2017, 97, 63-70. [CrossRef]

8. Kumar, P.; Gupta, A.; Dhakate, S.R.; Mathur, R.B.; Nagar, S.; Gupta, V.K. Covalent immobilization of xylanase produced from Bacillus pumilus SV-85S on electrospun polymethyl methacrylate nanofiber membrane. Biotechnol. Appl. Biochem. 2013, 60, 162-169. [CrossRef]

9. Naidja, A.; Huang, P.M.; Bollag, J.-M. Activity of tyrosinase immobilized on hydroxyaluminummontmorillonite complexes. J. Mol. Catal. A Chem. 1997, 115, 305-316. [CrossRef]

10. He, J.; Li, X.; Evans, D.G.; Duan, X.; Li, C. A new support for the immobilization of penicillin acylase. J. Mol. Catal. B Enzym. 2000, 11, 45-53. [CrossRef]

11. Kotha, A.; Selvaraj, L.; Rajan, C.R.; Ponrathnam, S.; Kumar, K.K.; Ambekar, G.R.; Shewale, J.G. Adsorption and expression of penicillin-G acylase immobilized onto methacrylate polymers generated with varying pore generating solvent volume. Appl. Biochem. Biotechnol. 1991, 30, 297-302. [CrossRef]

12. Chaga, G.S. Twenty-five years of immobilized metal ion affinity chromatography: Past, present and future. J. Biochem. Biophys. Methods 2001, 49, 313-334. [CrossRef]

13. Chaga, G.S.; Ersson, B.; Porath, J.O. Isolation of calcium-binding proteins on selective adsorbents application to purification of bovine calmodulin. J. Chromatogr. A 1996, 732, 261-269. [CrossRef]

14. Boccù, E.; Gianferrara, T.; Gardossi, L.; Veronese, F.M. E. coli penicillin acylase: Purification by affinity chromatography and covalent binding to nylon. Farmaco 1990, 45, 203-214.

15. Fitton, V.; Verdoni, N.; Sanchez, J.; Santarelli, X. Penicillin acylase purification with the aid of pseudo-affinity chromatography. J. Biochem. Biophys. Methods 2001, 49, 553-560. [CrossRef]

16. Armisén, P.; Mateo, C.; Cortés, E.; Barredo, J.L.; Salto, F.; Diez, B.; Rodés, L.; García, J.L.; Fernández-Lafuente, R.; Guisán, J.M. Selective adsorption of poly-His tagged glutaryl acylase on tailor-made metal chelate supports. J. Chromatogr. A 1999, 848, 61-70. [CrossRef]

17. Gibert, S.; Bakalara, N.; Santarelli, X. Three-step chromatographic purification procedure for the production of a His-tag recombinant kinesin overexpressed in E. coli. J. Chromatogr. B Biomed. Sci. Appl. 2000, 737, 143-150. [CrossRef]

18. Bresolin, I.T.L.; Borsoi-Ribeiro, M.; Tamashiro, W.M.S.C.; Augusto, E.F.P.; Vijayalakshmi, M.A.; Bueno, S.M.A. Evaluation of Immobilized Metal-Ion Affinity Chromatography (IMAC) as a Technique for IgG1 Monoclonal Antibodies Purification: The Effect of Chelating Ligand and Support. Appl. Biochem. Biotechnol. 2010, 160, 2148-2165. [CrossRef]

19. Hu, H.-L.; Wang, M.-Y.; Chung, C.-H.; Suen, S.-Y. Purification of VP3 protein of infectious bursal disease virus using nickel ion-immobilized regenerated cellulose-based membranes. J. Chromatogr. B 2006, 840, 76-84. [CrossRef]

20. Liu, Y.-C.; Changchien, C.-C.; Suen, S.-Y. Purification of penicillin G acylase using immobilized metal affinity membranes. J. Chromatogr. B 2003, 794, 67-76. [CrossRef]

21. Wu, C.-Y.; Suen, S.-Y.; Chen, S.-C.; Tzeng, J.-H. Analysis of protein adsorption on regenerated cellulose-based immobilized copper ion affinity membranes. J. Chromatogr. A 2003, 996, 53-70. [CrossRef]

22. Chen, C.-S.; Suen, S.-Y.; Lai, S.-Y.; Chang, G.R.-L.; Lu, T.-C.; Lee, M.-S.; Wang, M.-Y. Purification of capsid-like particles of infectious bursal disease virus (IBDV) VP2 expressed in E. coli with a metal-ion affinity membrane system. J. Virol. Methods 2005, 130, 51-58. [CrossRef]

23. Ke, Y.-M.; Chen, C.-I.; Kao, P.-M.; Chen, H.-B.; Huang, H.-C.; Yao, C.-J.; Liu, Y.-C. Preparation of the immobilized metal affinity membrane with high amount of metal ions and protein adsorption efficiencies. Process Biochem. 2010, 45, 500-506. [CrossRef]

24. Liu, Y.-C.; Suen, S.-Y.; Huang, C.-W.; Changchien, C.-C. Effects of spacer arm on penicillin G acylase purification using immobilized metal affinity membranes. J. Membr. Sci. 2005, 251, 201-207. [CrossRef] 
25. Pal, A.; Khanum, F. Covalent immobilization of xylanase on glutaraldehyde activated alginate beads using response surface methodology: Characterization of immobilized enzyme. Process Biochem. 2011, 46, 1315-1322. [CrossRef]

26. Dos Santos, J.P.; da Rosa Zavareze, E.; Dias, A.R.G.; Vanier, N.L. Immobilization of xylanase and xylanase- $\beta$-cyclodextrin complex in polyvinyl alcohol via electrospinning improves enzyme activity at awide $\mathrm{pH}$ and temperature range. Int. J. Biol. Macromol. 2018, 118, 1676-1684. [CrossRef]

27. Singh, V.; Kaul, S.; Singla, P.; Kumar, V.; Sandhir, R.; Chung, J.H.; Garg, P.; Singhal, N.K. Xylanase immobilization on magnetite and magnetite core/shell nanocomposites using two different flexible alkyl length organophosphonates: Linker length and shell effect on enzyme catalytic activity. Int. J. Biol. Macromol. 2018, 115, 590-599. [CrossRef]

28. Chen, C.-I.; Ko, Y.-M.; Shieh, C.-J.; Liu, Y.-C. Direct penicillin G acylase immobilization by using the self-prepared immobilized metal affinity membrane. J. Membr. Sci. 2011, 380, 34-40. [CrossRef]

29. Ko, Y.-M.; Chen, C.-I.; Shieh, C.-J.; Liu, Y.-C. Simultaneous purification and immobilization of d-hydantoinase on the immobilized metal affinity membrane via coordination bonds. Biochem. Eng. J. 2012, 61, $20-27$. [CrossRef]

30. Choi, S.K.; Ljungdahl, L.G. Dissociation of the cellulosome of Clostridium thermocellum in the presence of ethylenediaminetetraacetic acid occurs with the formation of trucated polypeptides. Biochemistry 1996, 35, 4897-4905. [CrossRef]

31. Craig, S.J.; Foong, F.C.; Nordon, R. Engineered proteins containing the cohesin and dockerin domains from Clostridium thermocellum provides a reversible, high affinity interaction for biotechnology applications. J. Biotechnol. 2006, 121, 165-173. [CrossRef]

32. Arora, R.; Behera, S.; Sharma, N.K.; Kumar, S. Bioprospecting thermostable cellulosomes for efficient biofuel production from lignocellulosic biomass. Bioresour. Bioprocess. 2015, 2, 38. [CrossRef]

33. Mongay, C.; Cerdà, V. A Britton-Robinson buffer of known ionic strength. Ann. Chim. 1974, 64, 409-412.

34. Amo, G.S.; Bezerra-Bussoli, C.; da Silva, R.R.; Kishi, L.T.; Ferreira, H.; Mariutti, R.B.; Arni, R.K.; Gomes, E.; Bonilla-Rodriguez, G.O. Heterologous expression, purification and biochemical characterization of a new xylanase from Myceliophthora heterothallica F.2.1.4. Int. J. Biol. Macromol. 2019, 131, 798-805. [CrossRef]

35. Elgharbi, F.; Hlima, H.B.; Farhat-Khemakhem, A.; Ayadi-Zouari, D.; Bejar, S.; Hmida-Sayari, A. Expression of A. niger US368 xylanase in E. coli: Purification, characterization and copper activation. Int. J. Biol. Macromol. 2015, 74, 263-270. [CrossRef]

36. Vitcosque, G.L.; Ribeiro, L.F.C.; de Lucas, R.C.; da Silva, T.M.; de Lima Damasio, A.R.; Farinas, C.S.; Gonçalves, A.Z.L.; Segato, F.; Buckeridge, M.S.; Jorge, J.A.; et al. The functional properties of a xyloglucanase (GH12) of Aspergillus terreus expressed in Aspergillus nidulans may increase performance of biomass degradation. Appl. Microbiol. Biotechnol. 2016, 100, 9133-9144. [CrossRef]

37. Mehnati-Najafabadi, V.; Taheri-Kafrani, A.; Bordbar, A.-K. Xylanase immobilization on modified superparamagnetic graphene oxide nanocomposite: Effect of PEGylation on activity and stability. Int. J. Biol. Macromol. 2018, 107, 418-425. [CrossRef]

38. Bailey, M.J.; Biely, P.; Poutanen, K. Interlaboratory testing of methods for assay of xylanase activity. J. Biotechnol. 1992, 23, 257-270. [CrossRef]

39. Bradford, M.M. A rapid and sensitive method for the quantitation of microgram quantities of protein utilizing the principle of protein-dye binding. Anal. Biochem. 1976, 72, 248-254. [CrossRef]

40. Laemmli, U.K. Cleavage of Structural Proteins during the Assembly of the Head of Bacteriophage T4. Nature 1970, 227, 680-685. [CrossRef]

41. Schneider, C.A.; Rasband, W.S.; Eliceiri, K.W. NIH Image to Image J: 25 years of image analysis. Nat. Methods 2012, 9, 671-675. [CrossRef]

Publisher's Note: MDPI stays neutral with regard to jurisdictional claims in published maps and institutional affiliations. 